\title{
Differences in Perceptions of Health Information Between the Public and Health Care Professionals: Nonprobability Sampling Questionnaire Survey
}

Anat Gesser-Edelsburg, PhD; Nour Abed Elhadi Shahbari, BSc, MHA; Ricky Cohen, BSN, MHA; Adva Mir Halavi, BSN; Rana Hijazi, BPharm, MPH; Galit Paz-Yaakobovitch, BSc, RD, MPH; Yael Birman, BSc, RD, MPH Health and Risk Communication Research Center and School of Public Health, Haifa, Israel

\section{Corresponding Author:}

Anat Gesser-Edelsburg, PhD

Health and Risk Communication Research Center and School of Public Health

University of Haifa

Haifa, 3498838

Israel

Phone: 972544243530

Fax: 97236322143

Email: ageser@univ.haifa.ac.il

\section{Abstract}

Background: In the new media age, the public searches for information both online and offline. Many studies have examined how the public reads and understands this information but very few investigate how people assess the quality of journalistic articles as opposed to information generated by health professionals.

Objective: The aim of this study was to examine how public health care workers (HCWs) and the general public seek, read, and understand health information and to investigate the criteria by which they assess the quality of journalistic articles.

Methods: A Web-based nonprobability sampling questionnaire survey was distributed to Israeli HCWs and members of the public via 3 social media outlets: Facebook, WhatsApp, and Instagram. A total of 979 respondents participated in the online survey via the Qualtrics XM platform.

Results: The findings indicate that HCWs find academic articles more reliable than do members of the general public (44.4\% and $28.4 \%$, respectively, $P<.001$ ). Within each group, we found disparities between the places where people search for information and the sources they consider reliable. HCWs consider academic articles to be the most reliable, yet these are not their main information sources. In addition, HCWs often use social networks to search for information (18.2\%, $P<.001)$, despite considering them very unreliable (only $2.2 \%$ found them reliable, $P<.001$ ). The same paradoxes were found among the general public, where $37.5 \%(P<.001)$ seek information via social networks yet only $8.4 \%(P<.001)$ find them reliable. Out of 6 quality criteria, 4 were important both to HCWs and to the general public.

Conclusions: In the new media age where information is accessible to all, the quality of articles about health is of critical importance. It is important that the criteria examined in this research become the norm in health writing for all stakeholders who write about health, whether they are professional journalists or citizen journalists writing in the new media.

(J Med Internet Res 2019;21(7):e14105) doi: $\underline{10.2196 / 14105}$

\section{KEYWORDS}

health information-seeking; reading and understanding; quality criteria for health journalists; Web-based and newspaper health information sources; journalistic articles; public healthcare workers and the general public

\section{Introduction}

\section{Searching for Web-Based Health Information}

In the last decade, the internet has become a powerful instrument for searching for health information because it provides the opportunity to access information from varied and diverse sources [1]. According to current estimates, over 4 billion people have access to the internet [2]. An analysis of global internet use indicates that Israelis are second among the top ten countries worldwide in time spent online among individuals age fifteen or above [3]. Israelis use the internet more than Americans and 
Europeans [4] and spend the most time on the internet among global users [5].

As for science and health-related information, Israelis exhibit high levels of interest in science, with $62 \%$ of the public stating that knowing about science and technology in their everyday life is a necessity [6]. Moreover, polls have documented that health-related news is the most popular news topic among Israelis [7]. A recent study of otolaryngology patients found that Israelis turn to the internet as a source of health information significantly more than to books or newspapers [8].

Numerous studies have focused on factors that influence users in searching for health information. One such factor is health literacy [9-13]. Low health literacy is related to the limited ability to search, understand, and assess Web-based health information [14-16]. In contrast, high health literacy leads to more frequent Web-based searches for medical information $[9,12]$.

Other variables found to influence the preference for internet sources include socioeconomic variables [13,17-19], cultural aspects [20,21], age variables [22-24], gender [25-28], and individual's level of self-efficacy [27,29,30].

One of the main consequences of searching for health information is its impact on actual behavior [31,32]. Some studies have indicated a connection between information seeking and actual behavioral improvement [33,34], with effective searching for Web-based health information leading to positive outcomes such as an improved understanding of medical conditions, an improved understanding of treatment options, informed decision making, and effective stress reduction [35-39]. On the contrary, Web-based health information can also contain misinformation and disinformation and can influence the behavior of people from various health fields [16,40-42].

\section{Traditional Information Sources Versus Web-Based Sources}

Before the digital age, the general public depended heavily on health organizations and official sources for health information. The digital revolution provided new alternatives that enabled laypersons to rely on additional and alternative information sources and to self-manage their information [43-45]. The internet revolution has made it possible for people to take an needs [46]. This process has led to a shift in the perceived role of the public, from passive recipient to active consumer of health information [16,45,47-49].

Web-based media constitute an important source of health-related information [50,51], as well as a platform for discussing and sharing personal experiences, opinions, and concerns regarding illnesses and treatments [49,52-57]. Furthermore, the internet serves as a democratic, accessible, and interactive source of diverse information, thus enabling patients to make informed decisions [58,59]. Seeking and sharing Web-based information provides people with social support while enabling them to maintain their anonymity $[60,61]$. active part in their medical care and manage their daily health

As a result of this revolution, health information no longer belongs exclusively to health professionals but rather is also accessible to the general public $[22,48,62]$. Thus, patients tend to bring information from Google to their appointments to discuss with their doctors so that the patient-physician discourse has changed from one-directional to two-directional communication [10,63-65]. During consultations with their doctors, patients seek to verify the information they obtained from other sources. After a doctor's appointment, some patients continue to search for information as a second opinion to verify the information they received from their doctor $[18,62,66,67]$. The reasons to continue searching information are as follows: the use of medical terminology in the physician-patient discourse impedes the patient's understanding [50] and the short duration of physician-patient encounters leads patients to seek other information sources to find answers to questions that remain open. These and other factors often lead the public to doubt the credibility of physicians and to consume medical information from Web-based sources [16,27,50].

In contrast, other studies show that despite the internet revolution, doctors are still considered the main source of reliable information [22,68-71]. Some studies indicate that searching for Web-based information can improve physician-patient communication [72]. Moreover, some patients do not see the internet as replacing the doctor but rather as another resource that can help them better understand medical recommendations [73]. Some studies indicate that consuming Web-based information also increases the public's reliance on medical professionals [74] for 2 main reasons: (1) the low reliability of the information on social networks $[14,18,63,75-79]$ and (2) the low level of health literacy among the public, which makes it difficult for patients to understand and integrate health information and motivates them to turn to physicians as reliable sources [80-82].

In addition to doctors, before the digital revolution, the main agents through which the public obtained medical information were traditional media sources (eg, television and the press) [22,83-87]. Journalists who write about health acted as middlemen in communicating information to the public $[16,42,88,89]$. In today's age of new media, professional journalists constitute a new voice in the discourse, alongside citizens who also define themselves as journalists $[16,42,90]$. Nevertheless, health journalists still play an important role because they are considered to be professionals by the general public, which continues to read their Web-based articles $[16,88,91]$. For example, the study by Pew Research Center reported that $95 \%$ of all new information being disseminated via news media came from old media-especially newspapers [87]. According to Walsh-Childers et al (2018), because patients become increasingly involved in the direction of their health care:

...health journalism will likewise increase in salience
for audiences as an education source. The current
climate encourages a level of patient involvement in
medical decision making that requires health care
consumers to have a much better understanding of
the benefits, harms, and costs of all options available
to them. [16]
(page number not for citation purposes) 
The literature analyzing journalistic quality points to the problematic nature of transmitting reliable information. Numerous studies over the past decade have found many problems in the media coverage of medications and medical treatments. These problems primarily emerge in the tendency toward sensationalism and over-enthusiasm in describing medications and medical technologies by placing excessive emphasis on their benefits while ignoring or hardly mentioning their risks, side effects, or costs [92-98]. The literature also found that journalists rely increasingly on websites and press releases from the medical industry and health organizations, which can result in the public perceiving professional journalism as biased and lacking credibility [42,99-101].

In light of the aforementioned changes, it is important to examine how the public in general and health care workers (HCWs) in particular assess the quality of the journalistic articles they read.

\section{The Quality of Health Information}

Retrieving Web-based information often leads to misinformation or disinformation [102]. The quality of the information offered on the internet varies, ranging from evidence-based scientific data quoting scientific research and clinical experiments to questionable information that could imperil the individual's health. Therefore, the challenge in searching for Web-based information and on social networks lies in the difficulty in finding sound, valid, and reliable information [103-105].

The proliferation of Web-based health information has led to a rise in the number of studies analyzing the quality of the published information. The first such study, published in 1997 by Impicciatore et al, evaluated the accuracy and integrity of the information on a website on fever management in children. According to the authors, out of 41 websites, only 4 provided full and accurate information about the subject [106]. This historic study provided a framework for subsequent studies of information quality. Accordingly, measurement tools were developed that usually included the following parameters: accuracy, completeness, readability, accountability, and technical criteria [103]. Additional specific parameters were added according to the subject of interest, for example, Eysenbach's 6 criteria [103], the WebMedQual Scale [107], and Godin's Quality Assurance Rating Tool for Internet Health Sites [108].

In recent years, these measurement tools and others have been used to assess information quality in different areas of medicine and health. All the studies point to the need to create reliable websites, improve information quality, improve access, increase oversight of Web-based medical information, and manufacture and distribute sound and customized materials [109-113]. Furthermore, websites have emerged that are dedicated to improving information quality for health writers. For example, the Health News Review website is an Australian-based website that aims to improve the public dialogue about health care by helping readers critically analyze health care news.

In general, most of the relevant literature in the new media age has focused on the reasons for seeking medical information, on diverse criteria that experts consider important to have on websites, and on the consequences of information seeking, whereas few studies have examined how the public reads and understands health information or what the public considers to be reliable.

This study sought to examine not only the ways in which the general public seeks information but also how the public understands this information and what information sources it sees as reliable. In addition, in view of the ongoing role of the press even in the new media era, the study also examines whether HCWs and the general public are capable of identifying quality criteria that influence behavioral intentions.

\section{Objectives}

This research had 2 main objectives:

1. To examine how HCWs and the general public seek out, read, and understand health information.

2. To examine perceptions among HCWs and the general public regarding criteria for judging the quality of journalistic articles.

The specific objectives included the following: (1) to examine the differences between the general public and HCWs in how they seek and read information and how this new information influences their behavior and (2) to examine the criteria readers use to determine the quality of an article written by a journalist.

Comparing HCWs with the general public is based on the following rationale: As part of their daily work routine, HCWs are required to read and understand up-to-date information to be able to answer questions posed by the public. In addition, the public expects HCWs to answer questions about the information it encounters [10,16,63-65,72,114,115]. This raises questions regarding whether $\mathrm{HCW}$ are able to discern the quality of journalistic information and whether they can refer the public to tools or criteria that can help in assessing the quality of articles appearing in the press.

The study is based on the following hypotheses:

1. The general public and HCWs will indicate that they will change their behavioral intentions after being exposed to health information.

2. The general public and HCWs will seek more health information from social networks than from scientific articles published in international journals.

3. The general public and HCWs will perceive scientific articles published in international journals as more reliable than information from social networks.

4. The general public and HCWs will be partially aware of the components that determine the quality of journalistic articles.

5. HCWs will perceive the criteria for determining the quality of health articles as more significant than will the general public.

\section{Methods}

A survey was distributed to Israeli HCWs and members of the public via 3 social media outlets: Facebook, WhatsApp, and Google+. A total of 979 respondents participated in the online 
survey via the Qualtrics XM platform. The research was approved by the Faculty of Social Welfare and Health Sciences Ethics Committee for research with human subjects at the University of Haifa (Approval no. 266/18).

\section{Study Design}

\section{Sampling}

Our sample was designed using Qualtrics XM online survey software as it provided rapid and efficient distribution of an interactive online questionnaire (see Multimedia Appendix 1) to our research population $(\mathrm{HCWs}$ and the general public in Israel). We used the self-selection in Web survey method of nonprobability sampling [116] to recruit participants through posts on social networks asking the general public (over the age of 18 years) to answer the survey.

Development of the Questionnaire and Research Procedure

\section{Stage 1: Building the Questionnaire}

The questions were based on a literature review in the field of health information seeking and on HealthNewsReview.org, an Australian website (https://www.healthnewsreview.org/) designed to rank health articles according to quality criteria. The questionnaire consisted of 3 parts. The first part asked the participant for sociodemographic details.
The second part included questions about information searching and reliability attributed to health information sources (eg, "Where do you usually search for information?" and "Which of the aforementioned information sources (social networks, health organization websites, human sources, web-based newspapers, public healthcare workers) do you consider the most reliable?"). Respondents were also asked about health issues that concern them: "What main health area usually interests and concerns you; what type of health information do you search for and read about?" Respondents chose from a list of medical topics: nutrition, physical activity, illnesses, medications, vaccinations, alternative therapies, safety, environmental exposure, and other. Questions also focused on how the public reads health articles (eg, "Do you read the whole article or just parts of it?") and the impact of the information on behavior change (eg, "If you encounter health information which seems important to you, to what extent would you change your behavior after learning about this?"). An example is information published by the World Health Organization indicating that processed meat raises the risk of cancer.

The third part of the questionnaire focused on what determines whether a health article is of high quality. Respondents were asked to rank the list of criteria they were given (see Table 1) on a 5-point Likert scale ranging from 1 (completely agree) to 5 (completely disagree).

Table 1. Importance of health information criteria to health care workers and to the general public.

\begin{tabular}{lll}
\hline Criteria & \multicolumn{2}{c}{ Respondents $^{\mathrm{a}}$} \\
& Health workers & \multicolumn{1}{c}{ General public } \\
\hline The article also presents the drawbacks of the intervention. & 4.27 & 4.13 \\
The "tone" of the article is more scientific than marketing. & 4.18 & 3.96 \\
The article presents alternatives to medical intervention. & 4.17 & 4.05 \\
The article is based on a number of articles. & 4.16 & 4.09 \\
Details of the study. & 4.06 \\
The article cites results from an article from an academic journal. & 4.04 \\
Presentation of quantitative findings and not personal stories. & 4.01 \\
The article presents a scientific controversy in the field. & 3.97 \\
The article notes the availability and accessibility of treatment to the general public. & 3.96 \\
The article explains and simplifies professional concepts. & 3.93 \\
The article presents an opposing professional opinion. & 3.76 \\
The article presents existing conflicts of interest of the researchers. & 3.75 \\
The article presents information that has implications for policy. & 3.72 \\
The article presents a response by the regulator. & 3.78 \\
The article presents the findings even in the event that science indicates that there are no unequivocal answers. & 3.68 \\
\hline
\end{tabular}

${ }^{\mathrm{a}}$ Respondents were asked to rank the list of criteria they were given on a 5-point Likert scale ranging from 1 (completely agree) to 5 (completely disagree).

\section{Stage 2: Criteria Validation Process}

Before distributing the questionnaire to each population group, we analyzed the validity of the criteria using a focus group consisting of 25 students and 7 researchers at the School of
Public Health (University of Haifa, Israel), who rated 3 health articles according to the criteria. We measured their overall percentage of agreement, as well as Krippendorff alpha (representing the level of agreement between coders beyond 
mere chance) for each answer [117]. Overall, for all the criteria, the between-coder agreement was satisfactory (alpha=.79; 92\%).

\section{Stage 3: Pilot Survey for Content Validation}

In the pilot, we distributed the questionnaire to $80 \mathrm{Arab}$ and Jewish members of the general public and HCWs. The participants were asked to provide feedback on the questionnaire's content. Subsequently, we focused on adjusting the questions to make them more culturally sensitive. For example, we used the word regulator in Hebrew, but as that term is not used in Arabic, we modified the word to policy. Similarly, conflict of interest is not a familiar concept in Arabic, so in the interest of clarity, an example was provided. Furthermore, as the general public did not always understand the full meaning of a question, we added clarifying examples. For instance, for the item stating that "The article gives possible solutions for different medical issues", we gave examples of a possible solution (eg, making a lifestyle change instead of taking medicine to lower high blood pressure).

\section{Stage 4: Running the Study}

To recruit as many participants as possible, we used intensive sampling in the first step and distributed the questionnaires via social media platforms (WhatsApp, Facebook, and Instagram). After this initial sampling, we continued to recruit participants through snowball sampling [118] to reach enough participants among HCWs by distributing the questionnaire via specialized HCW Web-based forums and by directly asking them to distribute the questionnaire to additional HCWs they knew.

At interim meetings during the survey, we monitored the social demographic variables and noted a lack of young men among the general public and the HCWs who responded to the survey. As our audience was a deliberate sample, we looked for ways to distribute the survey to more $\mathrm{HCW}$ and turned to health forums. By means of diffusion, the survey was distributed from our inner circles to extended circles.

\section{Analysis}

To check whether people intended to change their behavior after being exposed to health information, we used a chi-square test in which the answers are reduced to 3 levels (not at all or to a small extent, to a medium extent, and to a high to very high extent). Chi-square tests for independence were conducted to examine the differences between HCWs and others with regard to information seeking, sources of information, source reliability, and the manner in which the information was read. Wilcoxon Rank-Sum tests were used to examine the differences between $\mathrm{HCW}$ and the public regarding behavioral change following exposure to information and the criteria for a high-quality article.

Regarding the quality criteria for articles, separate chi-square tests were conducted for each criterion to examine the differences between HCWs and others. To avoid the inflation of a type I error owing to multiple testing, adjusted $\mathrm{P}$ values were calculated using the false discovery rate method.

\section{Results}

A total of 979 respondents participated in the survey. The vast majority of the respondents $(96 \%)$ were below retirement age $(<66$ years) and female (76\%), almost half were Jewish (49\%) and somewhat fewer (42\%) were Muslim. Table 2 depicts the respondents' sociodemographic and health status information. 
Table 2. Sociodemographic and health status characteristics $(n=979)$.

\begin{tabular}{|c|c|}
\hline Sociodemographic characteristics and category & $\mathrm{n}(\%)$ \\
\hline \multicolumn{2}{|l|}{ Gender } \\
\hline Male & $232(23.7)$ \\
\hline Female & $747(76.3)$ \\
\hline \multicolumn{2}{|l|}{ Age (years) } \\
\hline$<29$ & $363(37.1)$ \\
\hline $30-45$ & $397(40.6)$ \\
\hline $46-65$ & $177(18.1)$ \\
\hline $66+$ & $42(4.3)$ \\
\hline \multicolumn{2}{|l|}{ Ethnicity } \\
\hline Jewish & $481(49.1)$ \\
\hline Muslim & $410(41.9)$ \\
\hline Christian & $65(6.6)$ \\
\hline Druze & $12(1.2)$ \\
\hline Other & $11(1.1)$ \\
\hline \multicolumn{2}{|l|}{$\mathrm{HCW}^{\mathrm{a}}$} \\
\hline Yes & $363(37.1)$ \\
\hline No & $616(62.9)$ \\
\hline \multicolumn{2}{|l|}{ Suffering from a chronic disease } \\
\hline Yes & $203(20.7)$ \\
\hline No & $776(9.3)$ \\
\hline \multicolumn{2}{|l|}{ Child suffers from a chronic disease } \\
\hline Yes & $145(14.8)$ \\
\hline No & $834(85.2)$ \\
\hline
\end{tabular}

${ }^{\mathrm{a} H C W s: ~ h e a l t h ~ c a r e ~ w o r k e r s . ~}$

\section{Behavioral Intentions Following Exposure to Health Information: General Public Versus Health Care Workers}

Respondents were asked about the extent to which they would change their behavior after receiving health information of personal importance: "If you encounter health information that seems important to you, to what extent would you change your behavior following your exposure to this information?" The research findings indicate that more than half the HCWs and more than half the respondents from the general public reported they would change their behavior to a large or very large extent (Table 3).

Table 3. Intention to change behavior after receiving health information of personal importance. Question: If you encounter health information that seems important to you, to what extent would you change your behavior following exposure to this information?

\begin{tabular}{lllll}
\hline Respondents & $\begin{array}{l}\text { Intent to change } \\
\text { Not at all or to a low extent, } \mathrm{n}(\%)\end{array}$ & To a moderate extent, $\mathrm{n}(\%)$ & To a large or very large extent, $\mathrm{n}(\%)$ & Total \\
\hline $\mathrm{HCWs}^{\mathrm{a}}$ & $20(5.51)$ & $132(36.36)$ & $211(58.13)$ & 363 \\
$\mathrm{GP}^{\mathrm{b}}$ & $66(10.71)$ & $220(35.71)$ & $330(53.57)$ & 616 \\
Total & $86(8.78)$ & $352(35.96)$ & $541(55.26)$ & 979 \\
\hline
\end{tabular}

${ }^{\mathrm{a}} \mathrm{HCW}$ : health care workers.

${ }^{\mathrm{b}} \mathrm{GP}$ : general public. 
Seeking Health Information and Perceived Reliable Sources-the General Public Versus Health Care Workers

Table 4, Table 5 and Table 6 show where the general public and HCWs search for health information. In comparison with the general public, HCWs mainly search on health organization sites and in academic articles, as they consider academic articles more reliable. The general public seeks more information from social networks and Web-based newspapers and considers social networks, human resources, and HCWs to be more reliable.

Table 4. Seeking information and source reliability: comparison between health care workers and the general public.

\begin{tabular}{|c|c|c|c|c|c|c|}
\hline Sources for health information & Respondents, \% & $\mathrm{GP}^{\mathrm{a}}, \%$ & $\mathrm{HCWs}^{\mathrm{b}}, \%$ & Chi-square $(d f)$ & $P$ value & Adjusted $P$ value ${ }^{\mathrm{c}}$ \\
\hline \multicolumn{7}{|l|}{ Social networks } \\
\hline Where do you usually search for health information? & 30.34 & 37.50 & 18.18 & $40.33(1)$ & $<.001^{\mathrm{d}}$ & $<.001^{\mathrm{d}}$ \\
\hline Which source is most reliable in your opinion? & 6.13 & 8.44 & 2.20 & $15.45(1)$ & $<.001^{\mathrm{d}}$ & $<.001^{\mathrm{d}}$ \\
\hline \multicolumn{7}{|l|}{ Health organizations } \\
\hline Where do you usually search for health information? & 33.40 & 27.11 & 44.08 & $29.56(1)$ & $<.001^{\mathrm{d}}$ & $<.001^{\mathrm{d}}$ \\
\hline Which source is most reliable in your opinion? & 44.13 & 43.02 & 46.01 & $0.83(1)$ & .36 & .36 \\
\hline \multicolumn{7}{|l|}{ Human sources } \\
\hline Where do you usually search for health information? & 4.80 & 5.84 & 3.03 & $3.96(1)$ & .05 & .06 \\
\hline Which source is most reliable in your opinion? & 5.82 & 7.79 & 2.48 & $11.76(1)$ & $<.001^{\mathrm{d}}$ & $<.001^{\mathrm{d}}$ \\
\hline \multicolumn{7}{|l|}{ Academic articles } \\
\hline Where do you usually search for health information? & 17.06 & 12.82 & 24.24 & $21.05(1)$ & $<.001^{\mathrm{d}}$ & $<.001^{\mathrm{d}}$ \\
\hline Which source is most reliable in your opinion? & 34.32 & 28.41 & 44.35 & $25.76(1)$ & $<.001^{\mathrm{d}}$ & $<.001^{\mathrm{d}}$ \\
\hline \multicolumn{7}{|l|}{ Public health care workers } \\
\hline Where do you usually search for health information? & 5.52 & 5.68 & 5.23 & $0.09(1)$ & .77 & .77 \\
\hline Which source is most reliable in your opinion? & 8.27 & 10.71 & 4.13 & $13.04(1)$ & $<.001^{\mathrm{d}}$ & $<.001^{\mathrm{d}}$ \\
\hline \multicolumn{7}{|l|}{ Web-based newspapers } \\
\hline Where do you usually search for health information? & 8.89 & 11.04 & 5.23 & $9.51(1)$ & $.00^{\mathrm{e}}$ & $.00^{\mathrm{e}}$ \\
\hline Which source is most reliable in your opinion? & 1.33 & 1.62 & 0.83 & $1.11(1)$ & .29 & .35 \\
\hline
\end{tabular}

${ }^{\mathrm{a}} \mathrm{GP}$ : general public.

${ }^{\mathrm{b}} \mathrm{HCWs}$ : health care workers.

${ }^{\mathrm{c}}$ False discovery rate.

$\mathrm{d}_{P<.001}$

${ }^{\mathrm{e}} P<.05$.

Table 5. Primary information source and perception of reliability (percentage of health care workers).

\begin{tabular}{lll}
\hline Information source & Source used to search for information & Most reliable source \\
\hline Health organizations & $44 \%$ & $46 \%$ \\
Academic articles & $24 \%$ & $44 \%$ \\
Social networks & $18 \%$ & $2 \%$ \\
Public health workers & $5 \%$ & $4 \%$ \\
Human sources & $3 \%$ & $2 \%$ \\
Web-based newspapers & $5 \%$ & $1 \%$ \\
\hline
\end{tabular}


Table 6. Primary information source and perception of reliability (percentage of general public).

\begin{tabular}{lll}
\hline Information source & Source used to search for information & Most reliable source \\
\hline Health organizations & $27 \%$ & $43 \%$ \\
Academic articles & $13 \%$ & $28 \%$ \\
Social networks & $38 \%$ & $8 \%$ \\
Public health workers & $6 \%$ & $11 \%$ \\
Human sources & $6 \%$ & $8 \%$ \\
Web-based newspapers & $11 \%$ & $2 \%$ \\
\hline
\end{tabular}

\section{Health Care Workers Perceive the Criteria for Quality Health Articles as More Significant Than the General Public}

The differences between HCWs and the general public in their perceptions of the importance of health information quality criteria are statistically significant, with the exception of 2 criteria: the article explains and simplifies professional concepts and the article notes the availability and accessibility of treatment to the general public. Inclusion of the criteria in the articles is more important for HCWs than for the general public (Table 1).
The comparison between the criteria rankings of the HCWs and those of the general public shown in Table 1 indicates that both groups ranked the following criteria at the top of the list: intervention drawbacks; tone more scientific than commercial; offers alternatives to medical interventions; based on several articles; and details of the study. Among the HCWs, the importance of citing results from academic articles was next on the list, whereas the general public ranked this criterion in the tenth place, instead ranking presentation of quantitative findings and not personal stories in the sixth place. Both the HCWs and general public ranked conflict of interest at the bottom of the chart (not shown in Table 7).

Table 7. Ranking of top 6 health information criteria among health care workers versus the general public.

\begin{tabular}{|c|c|c|}
\hline Group and criteria & $\begin{array}{l}\text { 5-point Likert scale ranging from } 1 \text { (completely agree) to } 5 \\
\text { (completely disagree) }\end{array}$ & $P$ value $^{\mathrm{a}}$ \\
\hline \multicolumn{3}{|l|}{$\mathrm{HCWs}^{\mathrm{b}}$} \\
\hline Drawbacks of the intervention & 4.27 & $.01^{\mathrm{b}}$ \\
\hline Tone more scientific than commercial & 4.18 & $.00^{\mathrm{c}}$ \\
\hline Alternatives to medical interventions & 4.17 & $.04^{\mathrm{c}}$ \\
\hline Based on several articles & 4.16 & $<.0001^{\mathrm{d}}$ \\
\hline Details of the study & 4.09 & $.00^{\mathrm{c}}$ \\
\hline Cites results from academic articles & 4.06 & $<.0001^{\mathrm{d}}$ \\
\hline \multicolumn{3}{|l|}{ General public } \\
\hline Drawbacks of the intervention & 4.13 & $.00^{\mathrm{c}}$ \\
\hline Alternatives to medical interventions & 4.05 & $.04^{\mathrm{c}}$ \\
\hline Tone more scientific than commercial & 3.96 & $.00^{\mathrm{c}}$ \\
\hline Details of the study & 3.87 & $.00^{\mathrm{c}}$ \\
\hline Based on several articles & 3.86 & $<.0001^{\mathrm{d}}$ \\
\hline Presents quantitative findings and not personal stories & 3.84 & $.00^{\mathrm{c}}$ \\
\hline
\end{tabular}

${ }^{\mathrm{a} W i l c o x o n}$ Rank-sum Test

${ }^{\mathrm{b}} \mathrm{HCW}$ : health care workers.

${ }^{\mathrm{c}} P<.05$.

${ }^{\mathrm{d}} P<.001$ 


\section{Discussion}

\section{Principal Findings}

The new media age has changed the way people seek and consume health information $[1,46]$. The purpose of this study was to investigate not only how people search for Web-based and newspaper health information but also how they read and understand this information and what criteria they use to assess the quality of journalistic articles. It is important to examine how people read, understand, and assess the quality of journalistic health articles because health information can influence the way people shape their healthy lifestyles $[33,34,119,120]$.

The findings of this study confirm the importance of this examination. When participants were asked whether they intended to change their behavior after being exposed to health information, more than $30 \%$ responded that they would make moderate changes to their behavior and $50 \%$ responded that they would make extensive changes.

The findings indicate that HCWs focus their search for health information on health organization sites and in academic articles, whereas the general public tends to search more on social networks and Web-based newspapers. This finding can be explained by the HCWs' professional context [121]. Public $\mathrm{HCWs}$ are accustomed to interacting with the health system on a daily basis and naturally search more on health organization websites $[122,123]$. Similarly, it is reasonable to assume that in the course of their work, professionals are more likely to use academic articles than the general public [124].

Moreover, the difference in choice of information sources between HCWs and the general public can also be explained by the level of health literacy. It is reasonable to assume that HCWs have a higher level of health literacy and are more capable of processing and understanding complex medical information than the general public, leading them to place more trust in scientific sources than in social networks or information available on the internet $[12,125]$.

Furthermore, when participants were asked what they consider to be a reliable source, HCWs found academic articles more reliable than did the general public, which found social networks $[55,58,59]$, human sources, and HCWs to be more reliable $[68,74]$.

As for information seeking, HCWs found academic articles based on scientific facts to be more reliable than information from social networks. Moreover, they considered information based on scientific evidence from academic journals to be more reliable and to have a more scientific than commercial tone. Thus, differences between HCWs and the general public can be explained based on the training that HCWs undergo.

Nevertheless, when we examined each group separately, differences emerged within each group. Even though HCWs indicated that academic articles are the most reliable, they tended to search more for information on social networks despite considering them very unreliable [126]. We found a similar discrepancy among the general public, which considered health organizations and academic articles to be very reliable or reliable sources yet used them infrequently to search for health information, preferring social networks, which they considered unreliable. The research findings confirm our hypothesis that both HCWs and the general public search for health information on social networks more than they do in sources they consider reliable.

This discrepancy between perceptions and actual behavior is in line with studies indicating that there are situational factors whose influence is stronger than mere attitudes. According to Wicker (1969) [127], even though participants believe that health organizations and academic articles are more reliable sources than social networks, in practice, most of them search in sources they consider to be less reliable.

The following 3 explanations attempt to answer why the public seeks information from social networks more than from other sources. First, health organizations do not provide responses to the public's questions. That is, they conduct a monologue rather than a dialogue, leading the public to seek more information on social networks. The world of social media has generated a radical transformation in the relationship between government organizations and the public. Social media have changed the monologue to a dialogue in which anyone with information and access to communications technology can be a content creator and communicator [128]. Over the past decade, leading international health authorities, health ministries, and local governments have invested financial and human resources to narrow the gaps between the authorities and the public, thus increasing the authorities' presence on social media. Despite this impressive transformation, the use of social media by organizations is still in its infancy. Although the literature indicates that health authorities use social media, it also shows that this use is still very limited, as these tools serve primarily for mass information dissemination (similar to traditional mass media) instead of for 2-way communication [129-132].

Second, as health organizations do not exercise complete transparency in conveying information, the public turns to social networks to fill in the missing information. It is important to note that alongside disinformation deliberately conveyed by stakeholders, most of the discourse on social media stems from people's desire to obtain additional information, which is sometimes not fully conveyed by the health organizations [43].

Third, among the general public as well as among HCWs, decision making on health matters entails a combination between the automatic emotional system and the rational system. Thus, it is no wonder that despite being aware that social networks are likely to contain misinformation or disinformation, people continue to seek information there [133]. Studies of the health behavior of public HCWs found that they shared the same concerns and barriers as the general public [43,134-137]. Neither public HCWs nor the general public rely only on analytical or evidence-based information (academic articles) when searching for health information, but also seek information based on experience and emotions, both of which are found mostly on the social networks.

In summary, we proposed several possible explanations for the discrepancy we found between what the public and HCWs 
believe to be reliable and where they actually search for information in practice.

As for the research findings about what criteria the general public uses to judge the quality of journalistic articles compared with the criteria used by public HCWs, statistically significant differences were found between the importance of the criteria (except for 2), indicating that HCWs attributed more importance to the criteria than the public.

In addition, when we examined the 6 criteria that were most important to the general public and to HCWs, we found that 4 were important for both groups: drawbacks of the intervention, a tone that is more scientific than commercial, alternatives to medical interventions, and details of the study. These criteria indicate that the public values providing full information about the negative impacts or limitations of medical interventions as well as existing alternatives, information often absent from the media coverage. Studies have found that media coverage of medications and medical treatments is problematic, primarily in its tendency to provide sensational and an overly enthusiastic coverage of drugs and medical technologies and to emphasize the benefits excessively while ignoring or hardly mentioning the risks, side effects, and costs [93,94,96,97,98] or the limitations of scientific studies advocating the efficacy of these drugs.

In addition to the 4 aforesaid criteria cited both by public HCWs and by the general public as indications of information quality, 2 specific criteria emerged as important to the public. One of them is that the article should mention treatment availability and accessibility. This finding can be explained by the public's wish to know whether the treatment or medication mentioned in the article is accessible to it. For marketing reasons, press reports often mention medications and interventions that are not accessible to the public [92]. A second criterion valued by the public is that the article should simplify professional concepts. The importance of communicating professional information in understandable and clear language is a basic principle cited in the health communication and risk communication literature [138,139]. The mental models approach [140] also emphasizes the importance of understanding and simplifying professional concepts for the general public. Conversely, a criterion the public did not consider important was citing academic sources.

The findings also indicate that both $\mathrm{HCWs}$ and the general public ranked conflict of interest at the bottom of the list. Studies indicate that for years journalists have relied on information provided to them by organizations and the pharmaceutical industry rather than looking for quotes from academic sources themselves [99,100]. Several scholars have warned that journalists often fail to disclose the funding sources supporting the research, the investigators' financial conflicts of interests, and all the sources interviewed [95,141-143]. Owing to such potential conflicts of interest, reporting a study's limitations, funding sources, and financial ties is of great importance [144]. The Statement of Principles of the US Association of Health Care Journalists calls on journalists to disclose relevant conflicts of interest in their sources as a routine part of their work [145].
Yet, it seems that more often than not, journalists do not report such conflicts of interest [97,98,145].

The public may have become used to reading information in such a way that it does not look for citations from academic sources but relies on the author's integration or summary. In addition, the lack of discussion about the importance of exposing conflicts of interest leads both public HCWs and the general public not to attach adequate importance to this issue. The importance of including scientific articles and assessing their quality and the importance of disclosing conflicts of interest are criteria whose absence can produce misinformation, partial information, or disinformation that affect the public's decision making.

\section{Limitations}

This study is not a representative sample of the general population of Israel. It used nonprobability sampling and measuring and was therefore vulnerable to selection bias from the outset.

Furthermore, in this study, we did not check the impact of several variables that might affect health-information searching behavior, both of the general public and of health workers, such as age, gender, personal relevance, level of health literacy, and the individual's reasons for the health information search. Also, as in any study checking behavioral intentions and actual behavior, this study is vulnerable to information bias as the result of biased reporting by the respondents. Our overall goal was to reach the specific target audiences of the general public versus $\mathrm{HCW}$ s and compare them, even though it was not a representative sample of those 2 populations.

We took a number of steps to minimize sampling bias: (1) we used 3 different media channels, thus increasing the chances for randomization in this sample [116]; (2) we monitored the data once a week to insure sufficient professional and ethnic representation among the participants. For example, when we discovered that there was an insufficient number of HCWs, we posted on more medical forums. When we noticed there were not enough participants from the Arab sector, we appealed specifically to this population group and thus broadened the sample; and (3) we used snowball sampling according to which each participant gave the questionnaire to someone else from their group, enabling us to reach more people from the required population groups. As our study is based on a small subpopulation of HCWs, the choice of the snowball sampling technique seemed to be more appropriate than convenience sampling. In addition, the descriptive statistics suggest that we were able to achieve a diverse sample based on sociodemographic variables.

\section{Conclusions}

The study findings point to disparities both among HCWs and among the general public in their information-seeking behavior and their evaluations of the reliability of the sources searched. To reduce these gaps, health organizations must provide attractive materials, make academic articles accessible, and improve their dialogue with the public. In addition, in the technological age, where information is accessible to all, the quality of articles about health is critically important. Making 
the criteria cited in this research the norm in health writing is important for all stakeholders who write about health, whether

they are professional journalists or citizen journalists in the new media.

\section{Acknowledgments}

The authors wish to thank Ofir Raichman for his comments and suggestions at the early stages of the research and Dr Debby Mir for reading and editing the final version of manuscript.

\section{Conflicts of Interest}

None declared.

\section{Multimedia Appendix 1}

Questionnaire.

[DOCX File, 33KB-Multimedia Appendix 1]

\section{References}

1. Galarce EM, Ramanadhan S, Weeks J, Schneider EC, Gray SW, Viswanath K. Class, race, ethnicity and information needs in post-treatment cancer patients. Patient Educ Couns 2011 Dec;85(3):432-439. [doi: 10.1016/j.pec.2011.01.030] [Medline: 21354761]

2. Internet World Stats. Internet Usage Statistics. The Internet Big Picture. World Internet Users and 2019 Population Stats URL: https://www.internetworldstats.com/stats.htm [accessed 2019-06-04] [WebCite Cache ID 78sdvcoJQ]

3. Israelashvili M, Kim T, Bukobza G. Adolescents' over-use of the cyber world--Internet addiction or identity exploration? J Adolesc 2012 Apr;35(2):417-424. [doi: 10.1016/j.adolescence.2011.07.015] [Medline: 21803411]

4. Gordon G, Rosenbloom T, Greifman Y, Zwillenberg P. The Boston Consulting Group. 2014 Jul. Digital Bloom. How Israeli consumers value Online media URL: https://www.bcg.com/about/people/experts/Tal-Rosenbloom.aspx [accessed 2019-06-04] [WebCite Cache ID 78seirjeG]

5. Epstein M. Haaretz. 2013 May 23. Israelis 'like' Facebook more than any other nation URL: https://www.haaretz.com/ israel-news/business/.premium-israelis-like-facebook-more-than-other-nations-1.5268793 [accessed 2019-06-04] [WebCite Cache ID 78sfaviW0]

6. Dgani A, Dgani R. [The Seventh Eye Media and press criticism]. 2015 Apr. Perceptions and attitudes of the Israeli public science and space technology URL: https://cdn.the7eye.org.il/uploads/2015/06/ \%D7\%A1\%D7\%A7\%D7\%A8-\%D7\%AA\%D7\%A4\%D7\%99\%D7\%A1\%D7\%95\%D7\%AA.pptx [accessed 2019-06-04] [WebCite Cache ID 78sg9n0Y2]

7. Israel Internet Association. 2009. Using sources of information on health and medicine in Israel URL: https://www.isoc.org.il/ wp-content/uploads/2012/07/searchinghealthonline.pdf [accessed 2019-06-04] [WebCite Cache ID 78sgTAsKe]

8. Segal N, Gluck O, Sternbach D, Plakht Y, Segal A, Bachner YG. What are the sources for health information among patients attending otolaryngology outpatient clinics in Israel? A questionnaire survey. Br J Med Med Res 2015;5(6):775-779 [FREE Full text] [doi: 10.9734/BJMMR/2015/13506]

9. Britt RK, Hatten KN. Need for cognition and electronic health literacy and subsequent information seeking behaviors among university undergraduate students. SAGE Open 2013 Oct 29;3(4):1-10 [FREE Full text] [doi:

$\underline{10.1177 / 2158244013508957]}$

10. Lee K, Hoti K, Hughes JD, Emmerton LM. Consumer Use of. J Med Internet Res 2015 Dec 29;17(12):e288 [FREE Full text] [doi: 10.2196/jmir.4345] [Medline: 26715363]

11. Mitsutake S, Shibata A, Ishii K, Oka K. Association of eHealth literacy with colorectal cancer knowledge and screening practice among internet users in Japan. J Med Internet Res 2012;14(6):e153 [FREE Full text] [doi: 10.2196/jmir.1927] [Medline: 23149453]

12. Neter E, Brainin E. eHealth literacy: extending the digital divide to the realm of health information. J Med Internet Res 2012 Jan;14(1):e19 [FREE Full text] [doi: 10.2196/jmir.1619] [Medline: 22357448]

13. Oh YS, Choi EY, Kim YS. Predictors of smartphone uses for health information seeking in the Korean elderly. Social work in public health. Soc Work Public Health 2018;33(1):43-54. [doi: 10.1080/19371918.2017.1391150] [Medline: 29257932]

14. Diviani N, van den Putte B, Giani S, van Weert JC. Low health literacy and evaluation of online health information: a systematic review of the literature. J Med Internet Res 2015 May 7;17(5):e112 [FREE Full text] [doi: 10.2196/jmir.4018] [Medline: 25953147]

15. Meppelink CS, Smit EG, Diviani N, Van Weert JC. Health literacy and online health information processing: unraveling the underlying mechanisms. J Health Commun 2016;21(sup2):109-120. [doi: 10.1080/10810730.2016.1193920] [Medline: 27668318] 
16. Walsh-Childers K, Braddock J, Rabaza C, Schwitzer G. One step forward, one step back: changes in news coverage of medical interventions. Health Commun 2018 Dec;33(2):174-187. [doi: 10.1080/10410236.2016.1250706] [Medline: 27983868]

17. Dean CA, Geneus CJ, Rice S, Johns M, Quasie-Woode D, Broom K, et al. Assessing the significance of health information seeking in chronic condition management. Patient Educ Couns 2017 Aug;100(8):1519-1526. [doi: 10.1016/j.pec.2017.03.012] [Medline: 28320559]

18. Perez SL, Kravitz RL, Bell RA, Chan MS, Paterniti DA. Characterizing internet health information seeking strategies by socioeconomic status: a mixed methods approach. BMC Med Inform Decis Mak 2016 Dec 9;16:107 [FREE Full text] [doi: 10.1186/s12911-016-0344-x] [Medline: 27506607]

19. Tennant B, Stellefson M, Dodd V, Chaney B, Chaney D, Paige S, et al. eHealth literacy and Web 2.0 health information seeking behaviors among baby boomers and older adults. J Med Internet Res 2015 Mar 17;17(3):e70 [FREE Full text] [doi: 10.2196/jmir.3992] [Medline: 25783036]

20. Dutta MJ. Communicating about culture and health: theorizing culture-centered and cultural sensitivity approaches. Commun Theory 2007 Aug;17(3):304-328 [FREE Full text] [doi: 10.1111/j.1468-2885.2007.00297.x]

21. Kim W, Kreps GL, Shin CN. The role of social support and social networks in health information-seeking behavior among Korean Americans: a qualitative study. Int J Equity Health 2015 Apr 28;14:40 [FREE Full text] [doi:

10.1186/s12939-015-0169-8] [Medline: 25927546]

22. Jacobs W, Amuta AO, Jeon KC. Health information seeking in the digital age: an analysis of health information seeking behavior among US adults. Cogent Soc Sci 2017 Mar 13;3(1):1-11 [FREE Full text] [doi: 10.1080/23311886.2017.1302785]

23. Miller Soederberg LM, Bell RA. Online health information seeking: the influence of age, information trustworthiness, and search challenges. J Aging Health 2012 Apr;24(3):525-541. [doi: 10.1177/0898264311428167] [Medline: 22187092]

24. Zulman DM, Kirch M, Zheng K, An LC. Trust in the internet as a health resource among older adults: analysis of data from a nationally representative survey. J Med Internet Res 2011 Feb 16;13(1):e19 [FREE Full text] [doi: 10.2196/jmir.1552] [Medline: 21324832]

25. Ahadzadeh AS, Pahlevan Sharif S, Sim Ong F. Online health information seeking among women: the moderating role of health consciousness. Online Inf Rev 2018 Feb 12;42(1):58-72 [FREE Full text] [doi: 10.1108/OIR-02-2016-0066]

26. Altizer KP, Grzywacz JG, Quandt SA, Bell R, Arcury TA. A qualitative analysis of how elders seek and disseminate health information. Gerontol Geriatr Educ 2014;35(4):337-353 [FREE Full text] [doi: 10.1080/02701960.2013.844693] [Medline: 24188253]

27. Jaafar NI, Ainin S, Yeong MW. Why bother about health? A study on the factors that influence health information seeking behaviour among Malaysian healthcare consumers. Int J Med Inform 2017 Dec;104:38-44. [doi: 10.1016/j.ijmedinf.2017.05.002] [Medline: 28599815]

28. Manierre MJ. Gaps in knowledge: tracking and explaining gender differences in health information seeking. Soc Sci Med 2015 Mar;128:151-158. [doi: 10.1016/j.socscimed.2015.01.028] [Medline: 25618604]

29. Johnson JD, Case DO. Health Information Seeking, Volume 4. New York: Peter Lang Publishing Inc; 2012.

30. Lagoe C, Atkin D. Health anxiety in the digital age: an exploration of psychological determinants of online health information seeking. Comput Hum Behav 2015;52:484-491 [FREE Full text] [doi: 10.1016/j.chb.2015.06.003]

31. Johnson JD. Cancer-Related Information Seeking. Cresskill, NJ: Hampton Press; 1997.

32. Lambert SD, Loiselle CG. Health information seeking behavior. Qual Health Res 2007 Oct;17(8):1006-1019 [FREE Full text] [doi: 10.1177/1049732307305199] [Medline: 17928475]

33. Lee CJ, Zhao X, Pena-y-Lillo M. Theorizing the pathways from seeking and scanning to mammography screening. Health Commun 2016;31(1):117-128. [doi: 10.1080/10410236.2014.942769] [Medline: 26086195]

34. Moldovan-Johnson M, Martinez L, Lewis N, Freres D, Hornik RC. The role of patient-clinician information engagement and information seeking from nonmedical channels in fruit and vegetable intake among cancer patients. J Health Commun 2014 Dec;19(12):1359-1376 [FREE Full text] [doi: 10.1080/10810730.2014.906521] [Medline: 24875456]

35. Huang GJ, Penson DF. Internet health resources and the cancer patient. Cancer Invest 2008 Mar;26(2):202-207 [FREE Full text] [doi: 10.1080/07357900701566197] [Medline: 18259953]

36. Lustria ML, Noar SM, Cortese J, Van Stee SK, Glueckauf RL, Lee J. A meta-analysis of web-delivered tailored health behavior change interventions. J Health Commun 2013;18(9):1039-1069. [doi: 10.1080/10810730.2013.768727] [Medline: 23750972]

37. Rainie L, Fox S, Horrigan J, Lenhart A, Spooner T. Pew Internet. Tracking online life: How women use the Internet to cultivate relationships with family and friends URL: https://www.pewinternet.org/2000/05/10/ tracking-online-life-how-women-use-the-internet-to-cultivate-relationships-with-family-and-friends/ [accessed 2019-06-04] [WebCite Cache ID 78sjogrQG]

38. Wakefield MA, Loken B, Hornik RC. Use of mass media campaigns to change health behaviour. Lancet 2010 Oct 9;376(9748):1261-1271 [FREE Full text] [doi: 10.1016/S0140-6736(10)60809-4] [Medline: 20933263]

39. Ajzen I, Albarracín D, Hornik R. Prediction and Change of Health Behavior: Applying the Reasoned Action Approach. Mahwah, NJ: Lawrence Erlbaum Associates Publishers; 2007. 
40. Dixon G, Clarke C. The effect of falsely balanced reporting of the autism-vaccine controversy on vaccine safety perceptions and behavioral intentions. Health Educ Res 2013 Apr;28(2):352-359. [doi: 10.1093/her/cys110] [Medline: 23193194]

41. Eysenbach G. Infodemiology and infoveillance: framework for an emerging set of public health informatics methods to analyze search, communication and publication behavior on the internet. J Med Internet Res 2009 Mar 27;11(1):e11 [FREE Full text] [doi: 10.2196/jmir.1157] [Medline: 19329408]

42. Hinnant A, Jenkins J, Subramanian R. Health journalist role conceptions. Journalism Practice 2015 Aug 14;10(6):763-781 [FREE Full text] [doi: 10.1080/17512786.2015.1053509]

43. Gesser-Edelsburg A, Shir-Raz Y. Risk Communication and Infectious Diseases in an Age of Digital Media. London: Routledge; 2016.

44. Gesser-Edelsburg A, Walter N, Shir-Raz Y. The "new public" and the "good ol'press": Evaluating online news sources during the 2013 polio outbreak in Israel". Health Commun 2017 Dec;32(2):169-179. [doi: 10.1080/10410236.2015.1110224] [Medline: 27191949]

45. Sudau F, Friede T, Grabowski J, Koschack J, Makedonski P, Himmel W. Sources of information and behavioral patterns in online health forums: observational study. J Med Internet Res 2014 Jan 14;16(1):e10 [FREE Full text] [doi: 10.2196/jmir.2875] [Medline: 24425598]

46. Nasrabadi AN, Sabzevari S, Bonabi TN. Iranian women's experiences of health information seeking barriers: a qualitative study in Kerman. Iran Red Crescent Med J 2015 Feb;17(2):e25156 [FREE Full text] [doi: 10.5812/ircmj.25156] [Medline: $\underline{25834743}$ ]

47. McMullan M. Patients using the Internet to obtain health information: how this affects the patient-health professional relationship. Patient Educ Couns 2006 Oct;63(1-2):24-28. [doi: 10.1016/j.pec.2005.10.006] [Medline: 16406474]

48. Oh HJ, Lee B. The effect of computer-mediated social support in online communities on patient empowerment and doctor-patient communication. Health Commun 2012;27(1):30-41. [doi: 10.1080/10410236.2011.567449] [Medline: 21797714]

49. Fox S, Duggan M. Pew Internet. Washington, DC: Pew Research Center; 2013. Health online URL: https://www. pewinternet.org/2013/01/15/health-online-2013/ [accessed 2019-06-04] [WebCite Cache ID 78s17It0a]

50. Tustin N. The role of patient satisfaction in online health information seeking. J Health Commun 2010 Jan;15(1):3-17. [doi: 10.1080/10810730903465491] [Medline: 20390974]

51. Vance K, Howe W, Dellavalle RP. Social internet sites as a source of public health information. Dermatol Clin 2009 Apr;27(2):133-6, vi. [doi: 10.1016/j.det.2008.11.010] [Medline: 19254656]

52. Chew C, Eysenbach G. Pandemics in the age of Twitter: content analysis of Tweets during the 2009 H1N1 outbreak. PLoS One 2010 Nov 29;5(11):e14118 [FREE Full text] [doi: 10.1371/journal.pone.0014118] [Medline: 21124761]

53. Domanski MC, Cavale N. Self-reported. Aesthetic Plast Surg 2012 Dec;36(6):1292-1295. [doi: 10.1007/s00266-012-9977-z] [Medline: 23052381]

54. Kelly B, Hornik R, Romantan A, Schwartz JS, Armstrong K, DeMichele A, et al. Cancer information scanning and seeking in the general population. J Health Commun 2010 Oct;15(7):734-753 [FREE Full text] [doi: 10.1080/10810730.2010.514029] [Medline: 21104503 ]

55. Li Y, Wang X, Lin X, Hajli M. Seeking and sharing health information on social media: a net valence model and cross-cultural comparison. Technol Forecast Soc Change 2018 Jan;126:28-40 [FREE Full text] [doi: 10.1016/j.techfore.2016.07.021]

56. Szychta P, Zieliński T, Rykała J, Witmanowski H, Kruk-Jeromin J. Role of the internet in communication between patient and surgeon before rhinoplasty. J Plast Surg Hand Surg 2012 Sep;46(3-4):248-251. [doi: 10.3109/2000656X.2012.697376] [Medline: 22909242]

57. Yang Q, Beatty M. A meta-analytic review of health information credibility: belief in physicians or belief in peers? Health Inf Manag 2016 Aug;45(2):80-89. [doi: 10.1177/1833358316639432] [Medline: 27105476]

58. Beaudoin CE, Hong T. Health information seeking, diet and physical activity: an empirical assessment by medium and critical demographics. Int J Med Inform 2011 Aug;80(8):586-595. [doi: 10.1016/j.ijmedinf.2011.04.003] [Medline: 21640643]

59. Lee C, Ramírez AS, Lewis N, Gray SW, Hornik RC. Looking beyond the internet: examining socioeconomic inequalities in cancer information seeking among cancer patients. Health Commun 2012;27(8):806-817 [FREE Full text] [doi: 10.1080/10410236.2011.647621] [Medline: 22356137]

60. Gray NJ, Klein JD, Noyce PR, Sesselberg TS, Cantrill JA. Health information-seeking behaviour in adolescence: the place of the internet. Soc Sci Med 2005 Apr;60(7):1467-1478. [doi: 10.1016/j.socscimed.2004.08.010] [Medline: 15652680]

61. Li Y, Wang X. Seeking health information on social media: a perspective of trust, self-determination, and social support. J Organ End User Comput 2018;30(1):1-22. [doi: 10.4018/JOEUC.2018010101]

62. Clarke MA, Moore JL, Steege LM, Koopman RJ, Belden JL, Canfield SM, et al. Health information needs, sources, and barriers of primary care patients to achieve patient-centered care: a literature review. Health Informatics J 2016 Dec;22(4):992-1016. [doi: 10.1177/1460458215602939] [Medline: 26377952]

63. Hou J, Shim M. The role of provider-patient communication and trust in online sources in internet use for health-related activities. J Health Commun 2010;15(Suppl 3):186-199. [doi: 10.1080/10810730.2010.522691] [Medline: 21154093] 
64. Silver MP. Patient perspectives on online health information and communication with doctors: a qualitative study of patients 50 years old and over. J Med Internet Res 2015 Jan 13;17(1):e19 [FREE Full text] [doi: 10.2196/jmir.3588] [Medline: 25586865]

65. Wong DK, Cheung MK. Online health information seeking and eHealth literacy among patients attending a primary care clinic in Hong Kong: a cross-sectional survey. J Med Internet Res 2019 Mar 27;21(3):e10831 [FREE Full text] [doi: 10.2196/10831] [Medline: $\underline{30916666]}$

66. Lin WY, Zhang X, Song H, Omori K. Health information seeking in the Web 2.0 age: trust in social media, uncertainty reduction, and self-disclosure. Comput Hum Behav 2016 Mar;56:289-294 [FREE Full text] [doi: 10.1016/j.chb.2015.11.055]

67. Townsend A, Leese J, Adam P, McDonald M, Li LC, Kerr S, et al. eHealth, participatory medicine, and ethical care: a focus group study of patients' and health care providers' use of health-related internet information. J Med Internet Res 2015 Jun 22;17(6):e155 [FREE Full text] [doi: 10.2196/jmir.3792] [Medline: 26099267]

68. Chen X, Hay JL, Waters EA, Kiviniemi MT, Biddle C, Schofield E, et al. Health literacy and use and trust in health information. J Health Commun 2018;23(8):724-734. [doi: 10.1080/10810730.2018.1511658] [Medline: 30160641]

69. Chen X, Orom H, Hay JL, Waters EA, Schofield E, Li Y, et al. Differences in rural and urban health information access and use. J Rural Health 2018 Nov 16:1-13. [doi: 10.1111/jrh.12335] [Medline: $\underline{30444935]}$

70. Kelley MS, Su D, Britigan DH. Disparities in health information access: results of a county-wide survey and implications for health communication. Health Commun 2016;31(5):575-582. [doi: 10.1080/10410236.2014.979976] [Medline: 26452300]

71. Poínhos R, Oliveira BM, van der Lans IA, Fischer AR, Berezowska A, Rankin A, et al. Providing personalised nutrition: consumers' trust and preferenceing sources of information, service providers and regulators, and communication channelss regard. Public Health Genomics 2017;20(4):218-228. [doi: 10.1159/000481357] [Medline: 29050032]

72. Tan SS, Goonawardene N. Internet health information seeking and the patient-physician relationship: a systematic review. J Med Internet Res 2017 Dec 19;19(1):e9 [FREE Full text] [doi: 10.2196/jmir.5729] [Medline: 28104579]

73. Stevenson FA, Kerr C, Murray E, Nazareth I. Information from the internet and the doctor-patient relationship: the patient perspective--a qualitative study. BMC Fam Pract 2007 Aug 16;8:47 [FREE Full text] [doi: 10.1186/1471-2296-8-47] [Medline: 17705836$]$

74. Mendes Á, Abreu L, Vilar-Correia MR, Borlido-Santos J. "That Should Be Left to Doctors, That's What They are There For!"-Exploring the Reflexivity and Trust of Young Adults When Seeking Health Information. Health Commun 2017 Dec;32(9):1076-1081. [doi: 10.1080/10410236.2016.1199081] [Medline: 27485762]

75. Metzger MJ, Flanagin AJ. Using Web 2.0 technologies to enhance evidence-based medical information. J Health Commun 2011;16(Suppl 1):45-58. [doi: 10.1080/10810730.2011.589881] [Medline: 21843095]

76. Yang ZJ, Kahlor LA. What, me worry? the role of affect in information seeking and avoidance. Science Communication 2012 May 24;35(2):189-212 [FREE Full text] [doi: 10.1177/1075547012441873]

77. Ye Y. Correlates of consumer trust in online health information: findings from the health information national trends survey. J Health Commun 2011 Jan;16(1):34-49. [doi: 10.1080/10810730.2010.529491] [Medline: 21086209]

78. Yun EK, Park H. Consumers' disease information-seeking behaviour on the internet in Korea. J Clin Nurs 2010 Oct;19(19-20):2860-2868. [doi: 10.1111/j.1365-2702.2009.03187.x] [Medline: 20598000 ]

79. Agree EM, King AC, Castro CM, Wiley A, Borzekowski DL. "It's got to be on this page": age and cognitive style in a study of online health information seeking. J Med Internet Res 2015 Mar 24;17(3):e79 [FREE Full text] [doi: 10.2196/jmir.3352] [Medline: 25831483]

80. Cherla DV, Sanghvi S, Choudhry OJ, Jyung RW, Eloy JA, Liu JK. Readability assessment of Internet-based patient education materials related to acoustic neuromas. Otol Neurotol 2013 Sep;34(7):1349-1354. [doi: 10.1097/MAO.0b013e31829530e5] [Medline: 23921935]

81. Finnie RK, Felder TM, Linder SK, Mullen PD. Beyond reading level: a systematic review of the suitability of cancer education print and Web-based materials. J Cancer Educ 2010 Dec;25(4):497-505 [FREE Full text] [doi: 10.1007/s13187-010-0075-0] [Medline: 20237884]

82. Misra P, Kasabwala K, Agarwal N, Eloy JA, Liu JK. Readability analysis of internet-based patient information regarding skull base tumors. J Neurooncol 2012 Sep;109(3):573-580. [doi: 10.1007/s11060-012-0930-4] [Medline: 22810759]

83. Baker L, Wagner TH, Singer S, Bundorf MK. Use of the internet and e-mail for health care information: results from a national survey. J Am Med Assoc 2003 May 14;289(18):2400-2406. [doi: 10.1001/jama.289.18.2400] [Medline: 12746364]

84. Cotten SR, Gupta SS. Characteristics of online and offline health information seekers and factors that discriminate between them. Soc Sci Med 2004 Nov;59(9):1795-1806. [doi: 10.1016/j.socscimed.2004.02.020] [Medline: 15312915]

85. Dolan G, Iredale R, Williams R, Ameen J. Consumer use of the internet for health information: a survey of primary care patients. Int J Cons Stud 2004 Mar;28(2):147-153 [FREE Full text] [doi: 10.1111/j.1470-6431.2003.00363.x]

86. Dutta-Bergman MJ. Primary sources of health information: comparisons in the domain of health attitudes, health cognitions, and health behaviors. Health Commun 2004;16(3):273-288. [doi: 10.1207/S15327027HC1603_1] [Medline: 15265751]

87. Journalism.org. Washington, DC: Pew Research Center; 2010. How news happens: a study of the news ecosystem of one American city URL: https://www.journalism.org/2010/01/11/how-news-happens/ [accessed 2019-06-04] [WebCite Cache ID 78 soDJ0Fz] 
88. Geana MV, Kimminau KS, Greiner KA. Sources of health information in a multiethnic, underserved, urban community: does ethnicity matter? J Health Commun 2011 Jul;16(6):583-594. [doi: 10.1080/10810730.2011.551992] [Medline: 21391043]

89. Tu HT. Surprising decline in consumers seeking health information. Track Rep 2011 Nov(26):1-6. [Medline: 22121566]

90. Avery EJ, Lariscy RW, Sohn Y. Public information officers' and journalists' perceived barriers to providing quality health information. Health Commun 2009 Jun;24(4):327-336. [doi: 10.1080/10410230902889365] [Medline: 19499426]

91. Gaglio B, Glasgow RE, Bull SS. Do patient preferences for health information vary by health literacy or numeracy? A qualitative assessment. J Health Commun 2012;17(Suppl 3):109-121. [doi: 10.1080/10810730.2012.712616] [Medline: $\underline{23030565]}$

92. Brezis M. Who will look after the health of the media? Zman Harefuah 2002;1(6):44-46 [FREE Full text]

93. Bubela TM, Caulfield TA. Do the print media. CMAJ 2004 Apr 27;170(9):1399-1407 [FREE Full text] [Medline: 15111473]

94. Høye S, Hjortdahl P. [. Tidsskr Nor Laegeforen 2002 Jun 30;122(17):1671-1676 [FREE Full text] [Medline: 12555610]

95. Moynihan R, Sweet M. Medicine, the media and monetary interests: the need for transparency and professionalism. Med J Aust 2000;173(11-12):631-634. [Medline: 11379512]

96. Ransohoff DF, Ransohoff RM. Sensationalism in the media: when scientists and journalists may be complicit collaborators. Eff Clin Pract 2001;4(4):185-188. [Medline: 11525108]

97. Shuchman M, Wilkes MS. Medical scientists and health news reporting: a case of miscommunication. Ann Intern Med 1997 Jun 15;126(12):976-982. [Medline: 9182476]

98. Moynihan R, Bero L, Ross-Degnan D, Henry D, Lee K, Watkins J, et al. Coverage by the news media of the benefits and risks of medications. N Engl J Med 2000 Jun 1;342(22):1645-1650. [doi: 10.1056/NEJM200006013422206] [Medline: $10833211]$

99. Tanner AH, Friedman DB, Zheng Y. Influences on the construction of health news: the reporting practices of local television news health journalists. J Broadcast Electron Media 2015 May 28;59(2):359-376 [FREE Full text] [doi: $10.1080 / 08838151.2015 .1029123]$

100. Weitkamp E. On the roles of scientists, press officers and journalists. J Sci Commun 2014;13(03):1-3 [FREE Full text] [doi: $10.22323 / 2.13030501]$

101. Foster C, Tanner AH, Kim SH, Kim SY. National conversations about the costs of US health care. Sci Commun 2014 Jun 22;36(5):519-543. [doi: 10.1177/1075547014536882]

102. Shuyler KS, Knight KM. What are patients seeking when they turn to the internet? Qualitative content analysis of questions asked by visitors to an orthopaedics web site. J Med Internet Res 2003 Oct 10;5(4):e24 [FREE Full text] [doi: 10.2196/jmir.5.4.e24] [Medline: 14713652]

103. Eysenbach G, Powell J, Kuss O, Sa ER. Empirical studies assessing the quality of health information for consumers on the world wide web: a systematic review. J Am Med Assoc 2002;287(20):2691-2700. [Medline: 12020305]

104. Meric F, Bernstam EV, Mirza NQ, Hunt KK, Ames FC, Ross MI, et al. Breast cancer on the world wide web: cross sectional survey of quality of information and popularity of websites. Br Med J 2002 Mar 9;324(7337):577-581 [FREE Full text] [doi: 10.1136/bmj.324.7337.577] [Medline: 11884322]

105. Boyer C, Gaudinat A, Baujard V, Geissbühler A. Health on the Net Foundation: assessing the quality of health web pages all over the world. Stud Health Technol Inform 2007;129(Pt 2):1017-1021. [Medline: 17911869]

106. Impicciatore P, Pandolfini C, Casella N, Bonati M. Reliability of health information for the public on the World Wide Web: systematic survey of advice on managing fever in children at home. Br Med J 1997 Jun 28;314(7098):1875-1879 [FREE Full text] [doi: 10.1136/bmj.314.7098.1875] [Medline: 9224132]

107. Provost M, Koompalum D, Dong D, Martin BC. The initial development of the WebMedQual scale: domain assessment of the construct of quality of health web sites. Int J Med Inform 2006 Jan;75(1):42-57. [doi: 10.1016/j.ijmedinf.2005.07.034] [Medline: $\underline{16169770}$ ]

108. Godin S, Truschel J, Singh V. Quality assurance of self-help sites on the internet. J Prev Interv Community 2005 Jan 25;29(1-2):67-84 [FREE Full text] [doi: 10.1300/J005v29n01_05]

109. Dalton DM, Kelly EG, Molony DC. Availability of accessible and high-quality information on the internet for patients regarding the diagnosis and management of rotator cuff tears. J Shoulder Elbow Surg 2015 May;24(5):e135-e140. [doi: 10.1016/j.jse.2014.09.036] [Medline: 25457189]

110. Leira-Feijoo Y, Ledesma-Ludi Y, Seoane-Romero JM, Blanco-Carrión J, Seoane J, Varela-Centelles P. Available web-based dental implants information for patients. How good is it? Clin Oral Implants Res 2015 Nov;26(11):1276-1280. [doi: 10.1111/clr.12451] [Medline: 25041413]

111. Mozafarpour S, Norris B, Borin J, Eisner BH. Assessment of readability, quality and popularity of online information on ureteral stents. World J Urol 2018 Jun;36(6):985-992. [doi: 10.1007/s00345-018-2179-9] [Medline: 29435639]

112. Ritchie L, Tornari C, Patel PM, Lakhani R. Glue ear: how good is the information on the World Wide Web? J Laryngol Otol 2016 Feb;130(2):157-161. [doi: 10.1017/S0022215115003230] [Medline: 26805389]

113. Sacchi M, Yeung TM, Spinelli A, Mortensen NJ. Assessment of the quality of patient-orientated internet information on surgery for ulcerative colitis. Colorectal Dis 2015 Jun;17(6):511-514. [doi: 10.1111/codi.12870] [Medline: 25510335] 
114. Caiata-Zufferey M, Abraham A, Sommerhalder K, Schulz PJ. Online health information seeking in the context of the medical consultation in Switzerland. Qual Health Res 2010 Aug;20(8):1050-1061. [doi: 10.1177/1049732310368404] [Medline: 20442347]

115. Hu X, Bell RA, Kravitz RL, Orrange S. The prepared patient: information seeking of online support group members before their medical appointments. J Health Commun 2012;17(8):960-978. [doi: 10.1080/10810730.2011.650828] [Medline: 22574697]

116. Vehovar V, Toepoel V, Steinmetz S. Non-probability sampling. In: Wolf C, Joye D, Smith TW, Fu YC, editors. The SAGE Handbook of Survey Methodology. London: Sage Publications; 2016:329-345.

117. Hayes AF, Krippendorff K. Answering the call for a standard reliability measure for coding data. Commun Methods Meas 2007 Apr;1(1):77-89 [FREE Full text] [doi: 10.1080/19312450709336664]

118. Ulin P, Robinson ET, Tolley EE. Qualitative Methods in Public Health: A Field Guide for Applied Research. San Francisco, CA: Jossey-Bass; 2005.

119. Kreps GL. The pervasive role of information in health and health care: implications for health communication policy. Ann Int Commun Assoc 2016 May 18;11(1):238-276 [FREE Full text] [doi: 10.1080/23808985.1988.11678690]

120. Rubin A, Rubin B. Interface of personal and mediated communication: fifteen years later. Electr J Commun 2001;11(1):1 [FREE Full text]

121. Clarke MA, Belden JL, Koopman RJ, Steege LM, Moore JL, Canfield SM, et al. Information needs and information-seeking behaviour analysis of primary care physicians and nurses: a literature review. Health Info Libr J 2013 Sep;30(3):178-190 [FREE Full text] [doi: 10.1111/hir.12036] [Medline: 23981019]

122. Cao YG, Cimino JJ, Ely J, Yu H. Automatically extracting information needs from complex clinical questions. J Biomed Inform 2010 Dec;43(6):962-971 [FREE Full text] [doi: 10.1016/j.jbi.2010.07.007] [Medline: 20670693]

123. Norbert GL, Lwoga ET. Information seeking behaviour of physicians in Tanzania. Inf Dev 2012 Jul 9;29(2):172-182 [FREE Full text] [doi: 10.1177/0266666912450449]

124. Randell R, Mitchell N, Thompson C, McCaughan D, Dowding D. From pull to push: understanding nurses' information needs. Health Informatics J 2009 Jun;15(2):75-85. [doi: 10.1177/1460458209102969] [Medline: 19474221]

125. Mårtensson L, Hensing G. Health literacy - a heterogeneous phenomenon: a literature review. Scand J Caring Sci 2012 Mar;26(1):151-160 [FREE Full text] [doi: 10.1111/j.1471-6712.2011.00900.x] [Medline: 21627673]

126. McGowan BS, Wasko M, Vartabedian BS, Miller RS, Freiherr DD, Abdolrasulnia M. Understanding the factors that influence the adoption and meaningful use of social media by physicians to share medical information. J Med Internet Res 2012 Sep 24;14(5):e117 [FREE Full text] [doi: 10.2196/jmir.2138] [Medline: 23006336]

127. Wicker A. Attitudes versus actions: the relationship of verbal and overt behavioral responses to attitude objects. J Soc Issues 1969;25(4):41-78 [FREE Full text] [doi: 10.1111/j.1540-4560.1969.tb00619.x]

128. McNab C. What social media offers to health professionals and citizens. Bull World Health Organ 2009 Aug;87(8):566 [FREE Full text] [Medline: 19704998]

129. Neiger BL, Thackeray R, Burton SH, Giraud-Carrier CG, Fagen MC. Evaluating social media's capacity to develop engaged audiences in health promotion settings: use of Twitter metrics as a case study. Health Promot Pract 2013 Mar;14(2):157-162. [doi: 10.1177/1524839912469378] [Medline: 23271716]

130. Tausczik Y, Faasse K, Pennebaker JW, Petrie KJ. Public anxiety and information seeking following the H1N1 outbreak: blogs, newspaper articles, and Wikipedia visits. Health Commun 2012;27(2):179-185. [doi: 10.1080/10410236.2011.571759] [Medline: 21827326]

131. Thackeray R, Neiger BL, Burton SH, Thackeray CR. Analysis of the purpose of state health departments' tweets: information sharing, engagement, and action. J Med Internet Res 2013 Nov 11;15(11):e255 [FREE Full text] [doi: 10.2196/jmir.3002] [Medline: 24217361]

132. Thackeray R, Neiger BL, Smith AK, van Wagenen SB. Adoption and use of social media among public health departments. BMC Public Health 2012 Mar 26;12(1):242 [FREE Full text] [doi: 10.1186/1471-2458-12-242] [Medline: 22449137]

133. Tversky A, Kahneman D. The framing of decisions and the psychology of choice. Science 1981 Jan 30;211(4481):453-458. [Medline: $\underline{7455683}$ ]

134. Gesser-Edelsburg A, Walter N, Green MS. Health care workers-part of the system or part of the public? Ambivalent risk perception in health care workers. Am J Infect Control 2014 Aug;42(8):829-833. [doi: 10.1016/j.ajic.2014.04.012] [Medline: 24939516]

135. Heimberger T, Chang HG, Shaikh M, Crotty L, Morse D, Birkhead G. Knowledge and attitudes of healthcare workers about influenza: why are they not getting vaccinated? Infect Control Hosp Epidemiol 1995 Jul;16(7):412-415. [Medline: 7673647]

136. Marshall RJ. Influenza vaccine use among health care workers. Soc Market Q 2013 Sep 24;19(4):222-229 [FREE Full text] [doi: $10.1177 / 1524500413505096]$

137. Smedley J, Poole J, Waclawski E, Stevens A, Harrison J, Watson J, et al. Influenza immunisation: attitudes and beliefs of UK healthcare workers. Occup Environ Med 2007 Apr;64(4):223-227 [FREE Full text] [doi: 10.1136/oem.2005.023564] [Medline: $\underline{17182640]}$

138. Corcoran N. Communicating Health: Strategies for Health Promotion. Thousand Oaks, CA: Sage Publications; 2013. 
139. Du Pré A. Communicating About Health: Current Issues and Perspectives. Mountain View, CA: Mayfield Publishing Company; 2000.

140. Morgan MG, Fischhoff B, Bostrom A, Atman CJ. Risk Communication: A Mental Models Approach. Cambridge: Cambridge University Press; 2002.

141. Winsten JA. Science and the media: the boundaries of truth. Health Aff (Millwood) 1985;4(1):5-23. [Medline: 3997047]

142. Caulfield T. The commercialisation of medical and scientific reporting. PLoS Med 2004 Dec;1(3):e38 [FREE Full text] [doi: 10.1371/journal.pmed.0010038] [Medline: 15630461]

143. Kua E, Reder M, Grossel M. Science in the news: a study of reporting genomics. Public Underst Sci 2016 Aug 18;13(3):309-322 [FREE Full text] [doi: 10.1177/0963662504045539]

144. Cook DM, Boyd EA, Grossmann C, Bero LA. Reporting science and conflicts of interest in the lay press. PLoS One 2007 Dec 05;2(12):e1266 [FREE Full text] [doi: 10.1371/journal.pone.0001266] [Medline: 18060060]

145. Schwitzer G. How do US journalists cover treatments, tests, products, and procedures? An evaluation of 500 stories. PLoS Med 2008 May 27;5(5):e95 [FREE Full text] [doi: 10.1371/journal.pmed.0050095] [Medline: 18507496]

\section{Abbreviations}

HCW: health care worker

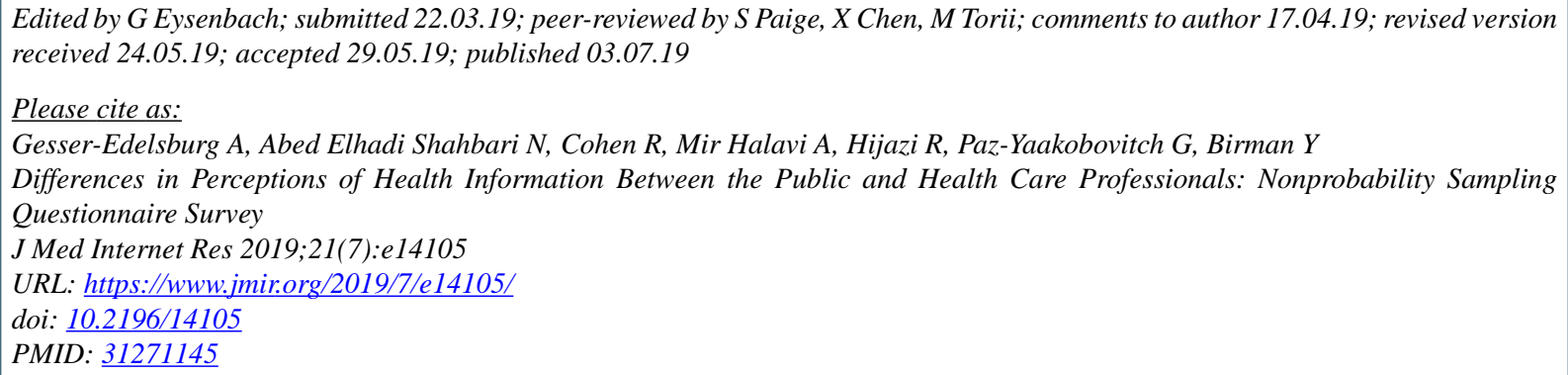

(C)Anat Gesser-Edelsburg, Nour Abed Elhadi Shahbari, Ricky Cohen, Adva Mir Halavi, Rana Hijazi, Galit Paz-Yaakobovitch, Yael Birman. Originally published in the Journal of Medical Internet Research (http://www.jmir.org), 03.07.2019. This is an open-access article distributed under the terms of the Creative Commons Attribution License (https://creativecommons.org/licenses/by/4.0/), which permits unrestricted use, distribution, and reproduction in any medium, provided the original work, first published in the Journal of Medical Internet Research, is properly cited. The complete bibliographic information, a link to the original publication on http://www.jmir.org/, as well as this copyright and license information must be included. 